\title{
Sildenafil, a phosphodiesterase-5-inhibitor decreased the oxidative stress induced by carbon tetrachloride in the rat kidney: A preliminary study
}

\author{
Anne A. Adeyanju', Olorunfemi R. Molehin ${ }^{2 *}$, Ezekiel T. Ige ${ }^{3}$, Lanre O. Adeleye ${ }^{2}$, Oluwakemi V. Omoniyi ${ }^{2}$ \\ ${ }^{1}$ Department of Biological Sciences, McPherson University, Seriki Sotayo, Ajebo, Ogun State Nigeria. \\ ${ }^{2}$ Department of Biochemistry, Faculty of Science, Ekiti State University, Ado-Ekiti. P.M.B.5363 Ado-Ekiti, Nigeria. \\ ${ }^{3}$ Department of Pharmacology and Therapeutics, College of Medicine, Ekiti State University, Ado-Ekiti. P.M.B.5363 Ado-Ekiti, Nigeria.
}

\section{ARTICLE INFO \\ Article history: \\ Received on: 09/09/2017 \\ Accepted on: 24/12/2017 \\ Available online: $27 / 02 / 2018$}

Key words:

Nephrotoxicity, adriamy-

cin, oxidative stress, rat,

sildenafil

\begin{abstract}
Carbon tetrachloride $\left(\mathrm{CCl}_{4}\right)$ is a well-established nephrotoxin. Free radical generation has been described as one of the mechanisms of inducing its nephrotoxicity. This preliminary study investigated the protective effect of sildenafil (SILD) in $\mathrm{CCl}_{4}$-induced oxidative stress in rat kidney. Thirty male albino wistar rats weighing between $150-200 \mathrm{~g}$ were randomly divided into five groups, each consisting of 6 rats. Control group received physiological saline $(10 \mathrm{ml} / \mathrm{kg}$, p.o.), another group received $0.5 \mathrm{ml} / \mathrm{kg} / \mathrm{i} . \mathrm{p}$. of $\mathrm{CCl}_{4}$ while three separate groups were pretreated with SILD at $5 \mathrm{mg}, 10 \mathrm{mg}$ and $20 \mathrm{mg} / \mathrm{kg}$ respectively before $\mathrm{CCl}_{4}$ challenge. Animals were sacrificed 24 hours after $\mathrm{CCl}_{4}$ administration. Renal biomarkers were measured in the serum. In addition, antioxidant assays and histopathological studies were carried out. $\mathrm{CCl}_{4}$ treatment produced no significant change in the serum levels of creatinine and BUN ( $\left.>0.05\right)$. However, $\mathrm{CCl}_{4}$ significantly $(\mathrm{p}<0.05)$ reduced GSH level by $43.8 \%$ and increased lipid peroxidation by $37.5 \%(\mathrm{p}<0.05)$ when compared to the group that received saline. Pretreatment with $10 \mathrm{mg}$ and $20 \mathrm{mg} / \mathrm{kg}$ doses of SILD significantly raised GSH level by $28.0 \%$ and $35.7 \%$ respectively while lipid peroxidation was reduced by $50 \%(\mathrm{p}<0.05)$ at $10 \mathrm{mg} / \mathrm{kg}$ dose of SILD. Low dose of SILD $(5 \mathrm{mg} / \mathrm{kg})$ was not effective as it caused a significant reduction of about $33.3 \%$ in GSH level $(\mathrm{p}<0.05)$. $\mathrm{CCl}_{4}$ significantly lowered the activities SOD, CAT and GST by $63.5 \%, 60.0 \%$ and $47.5 \%$ respectively when compared with the control group while GPx activity was decreased slightly by $17.0 \%$ ( $>>0.05$ ). SILD treatment at $10 \mathrm{mg} / \mathrm{kg}$ significantly elevated the activities of SOD, CAT, GPx, and GST (by $30.9 \%, 56.0 \%, 26.9 \%$ and $76.5 \%$ respectively) as compared with the $\mathrm{CCl}_{4}$-administered group while SILD at $5 \mathrm{mg} / \mathrm{kg}$ led to reductions of $71.8 \%, 18.0 \%$, $5.6 \%$ in the enzyme activities of SOD, CAT and GPx respectively. Sildenafil at highest dose of $20 \mathrm{mg} / \mathrm{kg}$ significantly produced a further increase in the activities of SOD and CAT by $33.0 \%$ and $64.0 \%$ respectively. Data generated from this preliminary study suggested that high dose of sildenafil may protect against the oxidative stress induced by $\mathrm{CCl}_{4}$ in the kidney of rats.
\end{abstract}

\section{INTRODUCTION}

The kidney is an organ involved in waste filtering and disposal in both human and animal bodies. It is also the target of so many xenobiotics during their metabolism. Carbon tetrachloride $\left(\mathrm{CCl}_{4}\right)$ is grouped under the class of the haloalkanes. It is

${ }^{*}$ Corresponding Author

Olorunfemi R. Molehin, Department of Biochemistry, Faculty of Science, Ekiti State University, Ado-Ekiti P.M.B. 5363, Ado-Ekiti, Nigeria.

E-mail: olorunfemi.molehin@eksu.edu.ng commonly used as fumigants, anthelmintics and an intermediate in chlorofluorocarbons synthesis (McGregor and Lang, 1996). $\mathrm{CCl}_{4}$ has been documented as a potent nephrotoxin found in animals (Ogeturk et al., 2005). Its toxicity was found to result from its conversion by CYP2E1, a cytochrome P450, to the reactive trichloromethyl $\left({ }^{*} \mathrm{CCl}_{3}\right)$ and peroxy trichloromethyl $\left({ }^{*} \mathrm{OOCCl}_{3}\right)$ radicals (Al-Sayed et al., 2015). These resultant radicals, then bind to the lipids of cell membrane to generate alkoxy $\left(\mathrm{R}^{*}\right)$ and peroxy radicals $\left(\mathrm{ROO}^{*}\right)$, which are highly toxic resulting into lipid peroxidation of cell membranes, cellular enzymes leakage 
(Khan et al., 2010), oxidative damage to the DNA, and ultimately death of kidney cells (Hismiogullari et al., 2015). Thus, processes involving reactive oxygen species (ROS) could be conveniently said to be contributing significantly to the etiology of $\mathrm{CCl}_{4}$ induced damage in the kidney.

Sildenafil (SILD) is phosphodiesterase-5 (PDE5) selective inhibitor, which participates in the degradation of cyclic guanosine monophosphate (cGMP) and relaxation of the smooth muscle cells of the arterioles (Gibson, 2001). Our recent study provided experimental evidence on the ability of SILD to offer protection against adriamycininduced hepatotoxicity via antioxidant mechanism (Adeyanju et al., 2016). In addition, positive effect in animals preconditioned with SILD in auto-transplanted kidneys has been reported (Lledo-Garcia et al., 2007). Moreover, SILD has also been found to reduce oxidative stress (Ebrahimi et al., 2009) and exert anti-inflammatory effect (RodriguezIturbe et al., 2005) through NO/cGMP pathway. Its ameliorative effect on cisplatin-induced nephrotoxicity has also been demonstrated (Elberry et al., 2014). In addition, Ali et al. (2011) has demonstrated the non-nephrotoxic potential of SILD. The study revealed that rats treated with sildenafil at a dose of $10 \mathrm{mg} \mathrm{kg}$, via subcutaneous route for five days had normal renal architecture. In this preliminary study, an investigation was carried out to determine the possible mechanisms of protection of sildenafil against nephrotoxicity induced by $\mathrm{CCl}_{4}$.

\section{MATERIALS AND METHODS}

\section{Chemicals and reagents}

Sildenafil citrate was purchased from Zurius Life sciences Pvt. Ltd. (India). Reduced glutathione (GSH), Ellman's reagent (5'5'-dithiobis-2-nitro benzoic acid), thiobarbituric acid (TBA) and trichloroacetic acid (TCA) were sourced from Sigma (St. Louis, MO, USA). Diagnostic assay kits for urea and creatinine determination were obtained from Randox Laboratories (Crumlin, U.K.). All other chemicals and reagents used in this experiment were of analytical grade.

\section{Animals}

Thirty male albino Wistar rats weighing $150-200 \mathrm{~g}$ were obtained from the Department of Biochemistry, College of Medicine University of Ibadan, Ibadan, Nigeria. The acclimatization of the rats was for two weeks and was randomly divided into 5 groups (six rats per group). The rats were placed in a conventional room with a 12 hours light/12 hours dark cycle. The rats were housed in plastic cages, had access to commercial diet and water was given ad libitum.

\section{Animal ethics}

The animals used received humane care in compliance with standard guidelines set up for the Care and Use of Laboratory Animals (NRC, 2011) for animal experiments. The ethic regulations have been duly observed in line with the established national and institutional guidelines for the protection of animals' welfare during experiments. Ethical approval was obtained from the Ethical Committee of the College of Health Sciences, Osun State University, Osogbo, Nigeria and given ethical approval number UNIOSUN/HREC/2017/A/009.

\section{Experimental design}

Rats were divided into 5 groups of 6 animals. Group 1 (control) was given normal saline $(10 \mathrm{~mL} / \mathrm{kg}$, p.o.). Group II was administered with a single dose of $\mathrm{CCl}_{4}(0.5 \mathrm{~mL} / \mathrm{kg})$ to induce nephrotoxicity. Groups III, IV and V were pre-treated with SILD $(5,10$ and $20 \mathrm{mg} / \mathrm{kg})$ for 7 days. Rats were sacrificed 24 hours after the $\mathrm{CCl}_{4}$ challenge. Section of the kidney was excised, fixed in $10 \%$ formalin for histopathology examination.

\section{Preparation of tissue homogenates}

Rats were sacrificed by cervical dislocation. Blood samples were collected into plain bottles prior to animal sacrifice and centrifuged at $3000 \mathrm{~g}$ at room temperature for 3 minutes to separate serum. The kidney was rapidly dissected and removed, rinsed in $1.15 \% \mathrm{KCl}$, blotted with Whatman filter paper and weighed. It was later placed in an ice cold phosphate buffer $\mathrm{pH} 7.4$ and homogenized in a Teflon-glass homogenizer. The centrifugation of the kidney homogenate was done at $12,000 \mathrm{~g}$ for 15 minutes at $4^{\circ} \mathrm{C}$ The post mitochondrial fractions obtained after centrifugation were stored at $4^{\circ} \mathrm{C}$ and used later for biochemical assays.

\section{Measurement of serum biomarkers for kidney function}

The creatinine and blood urea nitrogen (BUN) serum levels were determined using commercially available kits.

\section{Estimation of antioxidant parameters}

Assay of glutathione peroxidase (GPx) activity

The GPx activity was determined following the method of Lawerence and Burk (1961). $100 \mu \mathrm{L}$ of kidney homogenate was mixed with $800 \mu \mathrm{L}$ of $100 \mathrm{mM}$ potassium phosphate buffer (pH 7.4), which contains the mixture of $1 \mathrm{mM} \mathrm{NaN}_{3}, 1 \mathrm{mM}$ EDTA, $0.2 \mathrm{mM} \mathrm{NADPH}$, $1 \mathrm{U} / \mathrm{mL}$ GSH reductase and $1 \mathrm{mM} \mathrm{GSH}$. The reaction was started after 5mins by adding $2.5 \mathrm{mM} \mathrm{H}_{2} \mathrm{O}_{2}(100 \mu \mathrm{L})$ to the above mixtures. The absorbance changes was taken within 3 minutes and recorded at 340 $\mathrm{nm}$. The enzyme activity was calculated and the result was expressed by nmol NADPH/minute/mg protein.

\section{Assay of glutathione S-transferase (GST) activity}

The activity of GST was measured by the method of Habig et al. (1974). Briefly, $100 \mu \mathrm{L}$ of the kidney homogenate was mixed thoroughly with $880 \mu \mathrm{L}$ of phosphate buffer (pH 6.5, $100 \mathrm{mM}$ potassium) which contains the mixtures of $20 \mu \mathrm{L}$ of $50 \mathrm{mM}$ 1-chloro2,4-dinitrobenzene and $100 \mathrm{mM} \mathrm{GSH}$, and. Changes in absorbance was determined within 3 minutes at $340 \mathrm{~nm}$. The calculated enzyme activity was expressed by nmoll-chloro-2,4-dinitrobenzeneGSHconjugated formed/minute/mg protein.

\section{Assessment of lipid peroxidation}

Lipid peroxidation assay was determined by the method of Ohkawa et al. (1979). The formation of thiobarbituric reactive substances (TBARS) formed was measured at $532 \mathrm{~nm}$. The malonylaldehyde (MDA) level was calculated from the absorbance according to the method of Adam-Vizi and Seregi (1982) and expressed as nmol MDA/mg protein.

\section{Determination of reduced glutathione (GSH)}

The total sulfhydryl groups, protein-bound sulfhydryl groups, and free sulfhydryl groups (such as reduced GSH) in biological samples can be determined using Ellman's reagent (DTNB) as described by Jollow et al. (1974). A $2.5 \mathrm{~mL}$ of aliquot was mixed with 
an equal volume of $4 \%$ sulfosalicylic acid to facilitate deproteinization. The mixture was centrifuged at $14,000 \times g$ for $15 \mathrm{~min}$ at $4^{\circ} \mathrm{C}$. Then, 0.5 $\mathrm{mL}$ of the supernatant was mixed with $4.5 \mathrm{~mL}$ of Ellman's reagent and absorbance of the samples taken at $412 \mathrm{~nm}$. The blank was prepared by mixing $0.5 \mathrm{~mL}$ of diluted precipitating reagent (diluted twice with $0.1 \mathrm{M}$ phosphate buffer, $\mathrm{pH} 7.4$ ) with $4.5 \mathrm{~mL}$ of Ellman's reagent.

\section{Determination of superoxide dismutase (SOD) activity}

The level of SOD activity was determined spectrophotometrically as described by Misra and Fridovich (1972). One unit of SOD activity is defined as the quantity of SOD necessary to elicit $50 \%$ inhibition of the oxidation of adrenaline to adrenochrome in $1 \mathrm{~min}$. The activity was expressed as units/mg protein.

\section{Determination of catalase (CAT) activity of samples}

The catalase activity was estimated according to the method of Asru (1972). The $\mathrm{H}_{2} \mathrm{O}_{2}$ contents of the withdrawn solutions were subsequently determined kinectically at $25^{\circ} \mathrm{C}$. The results expressed as mmol $\mathrm{H}_{2} \mathrm{O}_{2}$ consumed/min/mgprotein.

\section{Determination of protein content of samples}

Protein determination in tissues was carried out using (Lowry et al., 1951) and the standard used was bovine serum albumin.

\section{Histological assessment}

A section of rat's kidney from different rats groups were fixed in 10\% neutral formalin solution. They were dehydrated in graded alcohol and embedded in paraffin. Fine sections obtained were mounted on glass slides and counter-stained with hematoxylin-eosin for light microscopic analyses. The slides were thereafter examined by a histopathologist who was blinded to the treatment groups after which photographs were taken.

\section{Data analysis}

Results were expressed as mean \pm standard error of mean. The statistical analysis were evaluated using one-way analysis of variance of Statistical Package for Social Sciences software for Windows version 16 (SPSS Inc., Redmond, WA, USA). Post hoc testing was done for intergroup comparisons using the least significant difference. The level of statistical significance was $p<0.05$.

\section{RESULTS}

\section{BUN and creatinine}

Effect of administration of SILD and $\mathrm{CCl}_{4}$ on serum creatinine and BUN levels is shown in Table 1. Notably, administration of $\mathrm{CCl}_{4}$ alone and the pretreatment with various doses of SILD produced no significant alterations on the levels of BUN and serum creatinine as compared to the normal and the group that received $\mathrm{CCl}_{4}$ respectively.

Table 1: Effect of SILD on $\mathrm{CCl}_{4}$-induced changes in the activities of the marker enzymes of kidney function.

\begin{tabular}{lcc}
\hline Treatment group & Urea & Creatinine \\
\hline Control $(\mathrm{NaCl})$ & $17.1 \pm 0.3$ & $1.2 \pm 0.03$ \\
$\mathrm{CCl}_{4}(0.5 \mathrm{~mL} / \mathrm{kg})$ & $16.3 \pm 0.3(4.9)^{\mathrm{a}}$ & $1.2 \pm 0.15(0)^{\mathrm{a}}$ \\
$\mathrm{SILD}(5 \mathrm{mg} / \mathrm{kg})+\mathrm{CCl}_{4}(0.5 \mathrm{~mL} / \mathrm{kg})$ & $16.0 \pm 0.43(1.9)^{\mathrm{b}}$ & $1.1 \pm 0.15(9.0)^{\mathrm{b}}$ \\
$\operatorname{SILD}(10 \mathrm{mg} / \mathrm{kg})+\mathrm{CCl}_{4}(0.5 \mathrm{~mL} / \mathrm{kg})$ & $13.8 \pm 0.99^{* *}(18.1)^{\mathrm{b}}$ & $1.2 \pm 0.12(0)^{\mathrm{b}}$ \\
$\operatorname{SILD}(20 \mathrm{mg} / \mathrm{kg})+\mathrm{CCl}_{4}(0.5 \mathrm{~mL} / \mathrm{kg})$ & $16.0 \pm 2.7(1.9)^{\mathrm{b}}$ & $0.7 \pm 0.1^{* *}(71.0)^{\mathrm{b}}$ \\
\hline
\end{tabular}

Values expressed as mean \pm standard error of mean (SEM) for five rats in each group. "Significantly different from control ( $<<0.05)$; ${ }^{* *}$ significantly different from $\mathrm{CCl}_{4}$-treated rats $(\mathrm{p}<0.05)$. Values in parenthesis represent $\%$ change; (a)\% change relative to control; ${ }^{(b)} \%$ change relative to $\mathrm{CCl}_{4}$.

\section{Effect of treatment on GSH and lipid peroxidation}

A significant reduction of $43.8 \%$ was observed in the level of $\mathrm{GSH}$ in $\mathrm{CCl}_{4}$-administered rats when compared to the control group. Administration of low dose of $5 \mathrm{mg} / \mathrm{kg}$ of SILD caused a reduction of about $33.3 \%$ in the level of GSH $(\mathrm{p}<0.05)$. However, higher doses of $10 \mathrm{mg}$ and $20 \mathrm{mg} / \mathrm{kg}$ of SILD significantly raised GSH level by $28.0 \%$ and $35.7 \%$ respectively. $\mathrm{CCl}_{4}$ treatment increased the MDA level (an index of lipid peroxidation) by $37.5 \%$ which was statistically different from the control group. Pretreatment with SILD at $10 \mathrm{mg} / \mathrm{kg}$ reduced the $\mathrm{CCl}_{4}$-induced elevation in renal MDA by $50 \%(\mathrm{p}<0.05)$ when compared with the $\mathrm{CCl}_{4}$-intoxicated rats (Table 2).

Table 2: Effect of SILD on $\mathrm{CCl}_{4}$-induced changes in GSH and MDA.

\begin{tabular}{ccc}
\hline Treatment group & $\begin{array}{c}\text { GSH } \\
(\boldsymbol{\mu g} / \text { gtissue })\end{array}$ & $\begin{array}{c}\text { MDA } \\
\text { (nmol/mgprotein) }\end{array}$ \\
\hline Control $(\mathrm{NaCl})$ & $32.0 \pm 2.5$ & $2.5 \pm 0.14$ \\
$\mathrm{CCl}_{4}(0.5 \mathrm{~mL} / \mathrm{kg})$ & $18.0 \pm 4.4^{*}(43.8)^{\mathrm{a}}$ & $4 \pm 1.7^{*}(37.5)^{\mathrm{a}}$ \\
$\mathrm{SILD}(5 \mathrm{mg} / \mathrm{kg})+\mathrm{CCl}_{4}(0.5 \mathrm{~mL} / \mathrm{kg})$ & $12.0 \pm 6.2^{* *}(33.3)^{\mathrm{b}}$ & $2.6 \pm 0.9(35.0)^{\mathrm{b}}$ \\
SILD $(10 \mathrm{mg} / \mathrm{kg})+\mathrm{CCl}_{4}(0.5 \mathrm{~mL} / \mathrm{kg})$ & $25.0 \pm 3.5^{* *}(28.0)^{\mathrm{b}}$ & $2.0 \pm 0.1^{* *}(50.0)^{\mathrm{b}}$ \\
SILD $(20 \mathrm{mg} / \mathrm{kg})+\mathrm{CCl}_{4}(0.5 \mathrm{~mL} / \mathrm{kg})$ & $28.0 \pm 2.5^{* *}(35.7)^{\mathrm{b}}$ & $2.7 \pm 0.4^{* *}(32.5)^{\mathrm{b}}$ \\
\hline
\end{tabular}

Values expressed as mean \pm standard error of mean (SEM) for five rats in each group. *Significantly different from control ( $<<0.05)$; ${ }^{* *}$ Significantly different from $\mathrm{CCl}_{4}$-treated rats $(\mathrm{p}<0.05)$. Values in parenthesis represent $\%$ change; ${ }^{\left({ }^{a}\right)} \%$ change relative to control; ${ }^{\left({ }^{b}\right)} \%$ change relative to $\mathrm{CCl}_{4}$. 


\section{Effect of treatment on antioxidant enzymes}

$\mathrm{CCl}_{4}$ challenge produced a significant decrease in the activities of SOD, CAT and GST by $63.5 \%, 60.0 \%$ and $47.5 \%$ respectively when compared with the group that received physiological saline while GPx activity was decreased slightly by $17.0 \%(\mathrm{p}>0.05)$ following the administration of $\mathrm{CCl}_{4}$. SILD treatment at $10 \mathrm{mg} / \mathrm{kg}$ resulted in a significant elevation in CAT, GPx, and GST activities (by $56.0 \%, 26.9 \%$ and $46.8 \%$ respectively) and non-significant increase in SOD activity (30.9\%) as compared with the $\mathrm{CCl}_{4}$-treated group. The highest dose of SILD $(20 \mathrm{mg} / \mathrm{kg})$ increased significantly the activities of catalase and GST by $64.0 \%$ and $66.7 \%$ respectively while SOD and GPx activities were nonsignificantly increased by $33.0 \%$ and $11.8 \%$ respectively (Table 3 ).

\section{Histopathological examination}

The photomicrographs of the histology done on the kidney tissue of rats in the various treatment groups are presented in Figure 1. The toxicity of $\mathrm{CCl}_{4}$ in the kidney was characterized by severe diffuse tubular and glomerular degeneration. $\mathrm{CCl}_{4}$-intoxicated rats treated with various doses of SILD showed no visible lesions.

Table 3: Effect SILDon $\mathrm{CCl}_{4}$-induced alterations in antioxidant parameters.

\begin{tabular}{|c|c|c|c|c|}
\hline Treatment group & $\begin{array}{c}\text { SOD } \\
\text { (units/gtissue) }\end{array}$ & $\begin{array}{c}\text { CAT } \\
\mathrm{H}_{2} \mathrm{O}_{2}(\mu \mathrm{mole} \text { consumed } / \mathrm{min})\end{array}$ & $\begin{array}{c}\text { GPx } \\
\text { (nmol/mgprotein/min) }\end{array}$ & $\begin{array}{c}\text { GST } \\
\text { (units/gtissue) }\end{array}$ \\
\hline Control $(\mathrm{NaCl})$ & $10.4 \pm 1.2$ & $10 \pm 0.18$ & $23.0 \pm 5.8$ & $8.0 \pm 0.76$ \\
\hline $\mathrm{CCl}_{4}(0.5 \mathrm{~mL} / \mathrm{kg})$ & $3.8 \pm 2.3^{*}(63.5)^{\mathrm{a}}$ & $0.4 \pm 0.01^{*}(60.0)^{\mathrm{a}}$ & $19.0 \pm 3.9(17.0)^{\mathrm{a}}$ & $4.2 \pm 1.4^{*}(47.5)^{\mathrm{a}}$ \\
\hline $\operatorname{SILD}(5 \mathrm{mg} / \mathrm{kg})+\mathrm{CCl}_{4}(0.5 \mathrm{~mL} / \mathrm{kg})$ & $1.07 \pm 1.1^{* *}(71.8)^{\mathrm{b}}$ & $0.33 \pm 0.01^{* *}(18.0)^{\mathrm{b}}$ & $18.0 \pm 8 .(5.6)^{\mathrm{b}}$ & $13.7 \pm 3.7(69.34)^{\mathrm{b}}$ \\
\hline $\operatorname{SILD}(10 \mathrm{mg} / \mathrm{kg})+\mathrm{CCl}_{4}(0.5 \mathrm{~mL} / \mathrm{kg})$ & $5.5 \pm 2.4(30.9)^{b}$ & $0.9 \pm 0.18^{* *}(56.0)^{\mathrm{b}}$ & $26.0 \pm 3.9^{* *}(26.9)^{\mathrm{b}}$ & $17.9 \pm 0.6^{* *}(76.5)^{\mathrm{b}}$ \\
\hline $\operatorname{SILD}(20 \mathrm{mg} / \mathrm{kg})+\mathrm{CCl}_{4}(0.5 \mathrm{~mL} / \mathrm{kg})$ & $5.7 \pm 2.9(33.0)^{b}$ & $1.1 \pm 0.46^{* *}(64.0)^{\mathrm{b}}$ & $17.0 \pm 5.0(11.8)^{\mathrm{b}}$ & $12 \pm 2.3^{* *}(66.7)^{b}$ \\
\hline
\end{tabular}

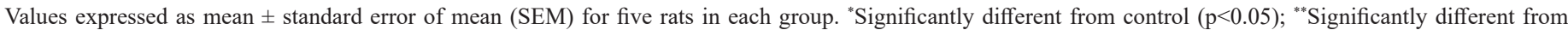
$\mathrm{CCl}_{4}$-treated rats $(\mathrm{p}<0.05)$. Values in parenthesis represent $\%$ change; (a) $\%$ change relative to control; ${ }^{\text {(b) }} \%$ change relative to $\mathrm{CCl}_{4}$.
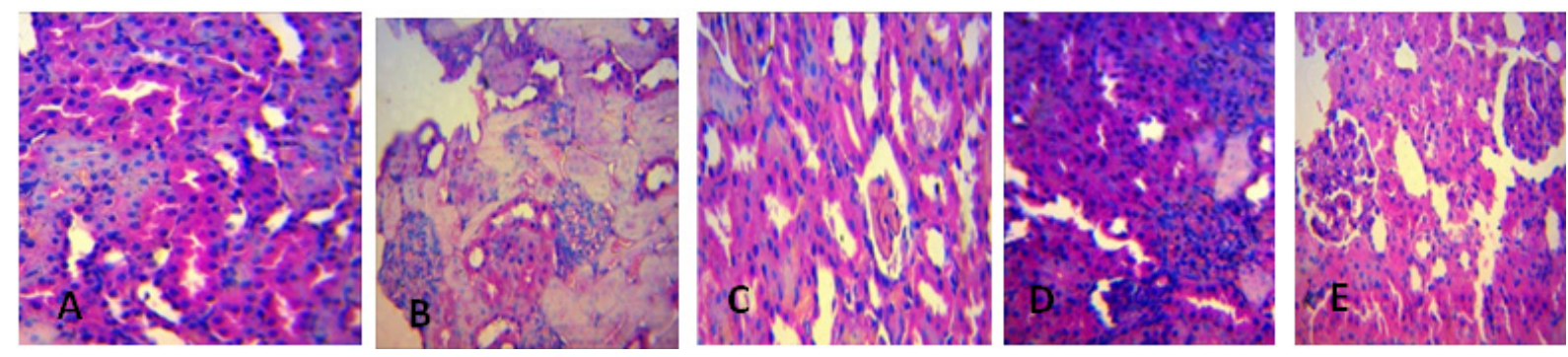

Fig. 1: Kidney section (x 400) of rat treated with $[\mathbf{A}]$ normal saline $(10 \mathrm{~mL} / \mathrm{kg})$ without visible lesions; $[\mathbf{B}] \mathrm{CCl}_{4}(0.5 \mathrm{~mL} / \mathrm{kg})$ showing a severe diffuse tubular and glomerular degeneration; [C] CCl + SILD $(5 \mathrm{mg} / \mathrm{kg})$ showing no visible lesions; [D] CCl ${ }_{4}+\operatorname{SILD~}(10 \mathrm{mg} / \mathrm{kg})$ showing no visible lesions; [E] CCl $4+\operatorname{SILD~}(20 \mathrm{mg} / \mathrm{kg})$ showing no visible lesions.

\section{DISCUSSION}

In this preliminary study, we did not observe any effect of $\mathrm{CCl}_{4}$ on kidney function as the levels of BUN and serum creatinine were not increased after $\mathrm{CCl}_{4}$ challenge. Our submission here is that, the short-term exposure of rats to $\mathrm{CCl}_{4}$ might be a contributing factor to this observation. In addition, the estimation of the renal function which was done just 24 hours after the administration of $\mathrm{CCl}_{4}$ may also not be sufficient to present a significant increase in creatinine and urea serum levels. Urea and creatinine are not reliable markers of early renal injury as they can remain unchanged at the early stage of the disease. Since oxidative stress parameters were significantly affected and histology revealed morphological damage, it implies there is an ongoing injury involving oxidative stress mechanism. Urea and creatinine levels usually become significantly elevated when renal damage is advanced so histology and oxidative stress parameters are sufficient to imply nephrotoxicity or renal damage with or without elevation of urea and creatinine. A study by Tirkey et al. (2005) and Zimmerman et al. (1983) also showed similar observation regarding the above observation on urea and creatinine levels in our present study. Ogawa et al. (1992) reported that $\mathrm{CCl}_{4}$ challenge did not cause an increase in BUN level in $\mathrm{Balb} / \mathrm{c}$ mice until after 12 weeks of its administration. Although our data showed no alterations in the renal function after 24 hours of $\mathrm{CCl}_{4}$ administration, the short-term exposure still resulted into a significant oxidative stress in the kidney. $\mathrm{CCl}_{4}$ has been reported to cause oxidative stress in the kidney with evidence of increase in lipid peroxidation and altered antioxidant status (Manna et al., 2006). Pre-treatment with SILD for 7 days obviously reduced the extent of lipid peroxidation induced by $\mathrm{CCl}_{4}$. This ability of SILD to ameliorate the level of lipid peroxidation induced by $\mathrm{CCl}_{4}$ treatment is in agreement with the report of Cadirci et al. (2011) who demonstrated that SILD decreased MDA level in the kidney of cecal ligation and puncture-induced septic rats. In addition, SILD was found to decrease the levels of MDA in the kidney of rats subjected to ischemia-reperfusion injury (Küçük et al., 2012) and studies by Morsy et al. (2014) also documented the efficacy of SILD as it significantly decreased the elevated MDA level in gentamicin-toxicity. Our finding in the present study is also in harmony with the reports of many researchers who had also shown 
that treatment with $\mathrm{CCl}_{4}$ significantly reduced renal $\mathrm{GSH}$ and this could alter the redox status of the cell. The reaction of the resultant metabolites from $\mathrm{CCl}_{4}$ with sulfhydryl groups of GSH and protein thiols has been attributed to this (Khan et al., 2009). The enhanced lipid peroxidation observed in this study might also be responsible for the reduced GSH level. However, administration of SILD for 7 days prior to $\mathrm{CCl}_{4}$ treatment significantly raised this reduced GSH level especially at the higher doses used in this study.

Furthermore, renal SOD, catalase, GPx and GST activities respectively were significantly decreased in the $\mathrm{CCl}_{4}$-treated rats. The reduction in the activity of SOD could be as a result of the increased lipid peroxidation observed earlier or the antioxidant enzymes inactivation which would ultimately result in superoxide radicals' accumulation, further promoting lipid peroxidation. In contrast, treatment with sildenafil demonstrated ability to increase SOD and CAT activities as also documented by Abdel-Latif et al. (2013) and Beheshtian et al. (2008) respectively. The higher doses, $10 \mathrm{mg}$ and $20 \mathrm{mg} / \mathrm{kg}$ of SILD used in our study consistently protected the antioxidant enzymes of the kidney from $\mathrm{CCl}_{4}$-induced oxidative stress. From histology point of view, pretreatment with SILD offered remarkable protection against kidney damage as shown in the intact renal architecture with no visible lesions.

In conclusion, data from this preliminary study supports the hypothesis that oxidative stress plays an important role in the mechanism of $\mathrm{CCl}_{4}$-induced nephrotoxicity and that SILD has therapeutic potential in preventing renal injury induced by $\mathrm{CCl}_{4}$ possibly via antioxidant mechanism.

\section{FINANCIAL SUPPORT AND SPONSORSHIP} Nil

\section{CONFLICT OF INTERESTS}

The authors declare that there is no conflict of interest.

\section{REFERENCES}

Abdel-Latif RG, Morsy MA, El-Moselhy MA, Khalifa MA. Sildenafil protects against nitric oxide deficiency-related nephrotoxicity in cyclosporine A treated rats. Eur J Pharmacol, 2013, 705 (1-3):126-134.

Adam-Vizi V, Seregi M. Receptor dependent stimulatory effect of noradrenaline on $\mathrm{Na}+\mathrm{K}+$ ATPase in rat brain homogenate: role of lipid peroxidation. Biochem Pharmacol, 1982, 31: 2231-2236.

Adeyanju AA, Ogunyemi AD, Owolabi O, Adesanya O, Omideyi T, Aina OO, Ekor M. Modulation of Adriamycin-induced Hepatotoxicity and Genotoxicity by Selective Inhibition of Phosphodiesterase-5 with Sildenafil in Wistar Rats. Toxicol Int, 2016, 23 (2): 153-158.

Ali BH, Abdelrahman1 AM, Al-Salam S, Sudhadevi M, AlMahruqi AS, Al-Husseni IS, Beegam S, Dhanasekaran S, Nemmar A, Al-Moundhri M. The Effect of Sildenafil on Cisplatin Nephrotoxicity in Rats. Basic \& Clinical Pharmacology \& Toxicology, 2011, 109: 300-308.

Al-Sayed E, Martiskainen O, Seif el-Din S, Abdel-Nasser $\mathrm{S}$, Olfat $\mathrm{H}$, Naglaa E.Protective effect of elargonium graveolens against carbon tetrachloride-induced hepatotoxicity in mice and haracterization of its bioactive constituents by HPLC-PDA-ESI-MS/MS analysis. Med Chem Res, 2015, 24: 1438-1448. 47: 389-94.

Asru KS. Colorimetric assay of catalase. Anal Biochem, 1972,

Beheshtian A, Salmasi AH, Payabvash S. Protective effects of sildenafil administration on testicular torsion/ detorsion damage in rats. World J Urol. 2008, 26 (2):197-202.

Cadirci Z, Halici F, Odabasoglu. Sildenafil treatment attenuates lung and kidney injury due to overproduction of oxidant activity in a rat model of sepsis: a biochemical and histopathological study. Clin Exp Immunol, 2011, 166 (3): 374-384.

Ebrahimi F. Shafaroodi, H, Asadi, S, Nezami BG, Ghasemi M, Rahimpour S, Hashemi M, Doostar Y, Dehpour AR. Sildenafil decreased cardiac cell apoptosis in diabetic mice: reduction of oxidative stress as a possible mechanism. Can J Physiol Pharmacol, 2009, 87: 556-564.

Elberry AA, Almohamadi MM. sildenafil ameliorates cisplatin-induced nephrotoxicity in wistar rats. World J Pharm Pharm Sci, 2014, 3(3): 151-161.

Gibson A.Phosphodiesterase 5 inhibitors and nitrergic transmission- from Zaprinast to Sildenafil. Eur J Pharmacol, 2001, 411:1-10

Habig WH, Pabst MJ, Jacoby WB. Glutathione-S-transferases: the first enzymatic step in mercaptoric acid formation. J Biol Chem, 1974, 249:7130-7139.

Hismiogullari AA, Hismiogullari SE, Karaca O, Sunay FB, Paksoy S, Can M, Kus I, Seyrek K, Yavuz O. The protective effect of curcumin administration on carbon tetrachloride (CCl4)-induced nephrotoxicity in rats. Pharmacol Rep, 2015, 67: 410-416.

Jollow DJ, Mitchell JR, Zampaglione N, Gillette JR. Bromobenzene induced liver necrosis: protective role of glutathione and evidence for 3,4 bromobenzene oxide as the hepatotoxic metabolite. Pharmacol, 1974, 11:151-169.

Khan MR, Rizvi W, Khan GN, Khan RA, Shaheen S. Carbon tetrachloride-induced nephrotoxicity in rats: protective role of Digera muricata. J Ethnopharmacol, 2009, 122: 91-99.

Khan RA, Khan MR, Sahreen S. Evaluation of Launaea procumbens use in renal disorders: A rat model. J Ethnopharmacol, 2010, 128:452-61.

Küçük, M. Yucel, N. Erkasap et al., "The effects of PDE5 inhibitory drugs on renal ischemia/reperfusion injury in rats," Mol Biol Rep, 2012, 39(10): 9775-9782.

Lawerence RA, Burk RF. Glutathione peroxidase activity in selenium-deficient rat's liver. Biochem Biophys Res Commun, 1961, 71: 952-958.

Lledo-Garcia E, Rodriguez-Martinez D, Cabello-Benavente R, Moncada-Iribarren I, Tejedor-Jorge A, Dulin E, Hernandez-Fernandez C, Del Canizo-Lopez JF. Sildenafil improves immediate post transplant parameters in warm-ischemic kidney transplants. Exp study Transplant Proc, 2007, 39:1354-1356.

Lowry OH, Rosenbrough NJ, Farr AL, Randall RJ. Protein measurement with Folin phenol reagent. J Biol Chem, 1951, 193: 265-275.

Manna P, Sinha M, Sil PC. Aqueous extract of Terminalia arjuna prevents carbon tetrachloride induced hepatic and renal disorders. BMC Complementary Alternat Med. 2006, 6: 33-33.

McGregor D, Lang M. Carbon tetrachloride: genetic effects and other modes of action. Mutat. Res, 1996, $366: 181-195$.

Misra HP, Fridovich I. The generation of superoxide radical during the antioxidant of hemoglobin. J Biol Chem, 1972, 247: 6960-6962.

Morsy MA, Ibrahim SA, Amin EF, Kamel MY, Rifaai RA, Hassan MK. Sildenafil Ameliorates Gentamicin-Induced Nephrotoxicity in Rats: Role of iNOS and eNOS. J Toxicol. 2014, http://dx.doi. org/10.1155/2014/489382.

National Research Council. Guide for the Care and Use of Laboratory Animals: Eighth Edition. Washington, DC: The National Academies Press. $2011 \mathrm{https} / / /$ doi.org/10.17226/12910.

Ogawa M, Mori T, Mori Y, Ueda S, Azemoto R, Makino Y, Wakashi Y, Ohto M, Wakashi M, Yoshida H. Study on chronic renal injuries induced by carbon tetrachloride: Selective inhibition of the nephrotoxicity by irradiation. Nephron, 1992, 60: 68-73.

Ogeturk M, Kus I, Colakoglu N, Zararsiz I, Ilhan N, Sarsilmaz M. Caffeic acid phenethyl ester protects kidneys against carbon tetrachloride toxicity in rats. J Ethnopharmacol, 2005, 97:273-280.

Ohkawa H, Ohishi N, Yagi K. Assay for lipid peroxides in animal tissues by thiobarbituric acid reaction. Anal Biochem. 1979, 95:351-358. 
Rodriguez-Iturbe B, Ferrebuz A, Vanegas QY, Espinoza F, Pons H, Vaziri, ND. Early treatment with cGMP phosphodiesterase inhibitor ameliorates progression of renal damage. Kidney Int, 2005, 68:2131-42.

Tirkey N, Pilkhwal S, Kuhad A,Kanwaljit C. Hesperidin, a citrus bioflavonoid, decrease the oxidative stress produced by carbon tetrachloride in rat liver and kidney. BMC Pharmacol, 2005, 5(2): 1-8.

Zimmerman SW, Norback DH, Powers K. Carbon tetrachloride nephrotoxicity in rats with reduced renal mass. Arch Pathol Lab Med, 1983,
107:264-269.

\section{How to cite this article:}

Adeyanju AA, Molehin OR, Ige ET, Adeleye LO, Omoniyi OV. Sildenafil, a phosphodiesterase-5-inhibitor decreased the oxidative stress induced by carbon tetrachloride in the rat kidney: A preliminary study. J App Pharm Sci, 2018; 8(02): 106-111. 